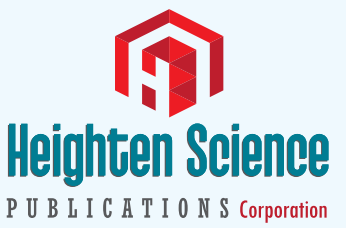

ISSN

2639-6629
*Address for Correspondence: Dr. Roberto Carlos Burini, Nutritional and Exercise Metabolism Center, UNESP School of Medicine, São Paulo State University, Brazil, Email: burini@fmb.unesp.br

Submitted: 04 March 2017

Approved: 10 May 2017

Published: 12 May 2017

Copyright: @ 2017 Burini RC, et al. This is an open access article distributed under the Creative Commons Attribution License, which permits unrestricted use, distribution, and reproduction in any medium, provided the original work is properly cited.

Keywords: Blood hypertension; Epigenetics; Drug-treatment costs; Lifestyle modificationtreatment

\title{
The lifestyle modification effectiveness
} in reducing Hypertension in a Brazilian Community: From the epigenetic basis of Ancestral Survival to the Contemporary

\section{Lifestyle and Public Health Initiatives}

\author{
Roberto Carlos Burini ${ }^{1,2 *}$, Hugo Tadashi Kano ${ }^{1,3}$, Mariana \\ Santoro Nakagaki ${ }^{1,4}$, Caroline das Neves Mendes Nunes ${ }^{1,3}$ and \\ Franz Homero Paganini Burini ${ }^{1,5}$ \\ ${ }^{1}$ Nutritional and Exercise Metabolism Center, UNESP School of Medicine, São Paulo State \\ University, Brazil \\ ${ }^{2}$ Dept. of Public Health, UNESP School of Medicine, Brazil \\ ${ }^{3}$ Graduate Student of Pathology, UNESP School of Medicine, São Paulo State University, Brazil \\ ${ }^{4}$ Graduate Student of Physical Education, Londrina State University (UEL), Physical Education \\ and Sport Center, Parana, Brazil \\ ${ }^{5}$ Sports Medicine Physician of the UNESP Medical School-Clinical Hospital, Brazil
}

\section{ABSTRACT}

High blood pressure (HBP) is a strong, independent and etiologically relevant risk factor for cardiovascular and therefore, the leading cause of preventable deaths worldwide. Hypertension has high medical and social costs. Due to its many associated complications, the use of medical services create high costs with medications which represent almost half of the estimated direct expenses. Free distribution of more than 15 medications for HyPERtension and DIAbetes (HIPERDIA program) clearly shows the important role of drugs in the Brazilian Government's effort to tackle these two diseases. Notwithstanding, the prevalence of HBP is rising in parallel with other NCDs. It is known that HBP results from environmental and genetic factors, and interactions among them. Our ancestors were often faced with survival stresses, including famine, water and sodium deprivation. As results of natural selection, the survival pressures drove our evolution to shape a thrifty genotype, which favored/ promoted energy-saving and sodium/water preservation. However, with the switch to a sodium- and energy-rich diets and sedentary lifestyle, the thrifty genotype and ancient frugal alleles, are no longer advantageous, and may be maladaptive to disease phenotype, resulting in hypertension, obesity and insulin resistance syndrome. Lowgrade chronic inflammation and oxidative stress would be the underlying mechanisms for these diseases. HBP is often associated with unhealthy lifestyles such as consumption of high fat and/or high-salt diets and physical inactivity. Therefore, alternatively to medicine drugs, lifestyle and behavioral modifications are stressed for the prevention, treatment, and control of hypertension. A lifestyle modification program (LSM) involving dietary counseling and regularly supervised physical activity ("Move for Health") has been used for decades, in our group, for NCDs primary care. Retrospective (2006-2016) data from 1317 subjects have shown the top quartile of blood pressure $(142.2 / 88.5 \mathrm{mmHg})$ differing from the lower quartile $(120.6 / 69.2 \mathrm{mmHg})$ by being older, with lower schooling, lower income and, lower physical activity and aerobic capacity. Additionally, the P75 showed higher intake of $\mathrm{CHO}$, saturated fat and sodium along with lower-diet quality score with a more processed foods. They showed higher body fatness and prevalence of metabolic syndrome along with higher pro-inflammatory and peroxidative activities and insulin resistance. In this free-demand sample, the HBP rate was $51.2 \%$ for SBP and $42.7 \%$ for DBP. The rate of undiagnosed HBP was $9.8 \%$ and only $1 / 3$ of medicated patients were controlled for HBP. After 10 weeks of LSM the HBP normalization achieved $17.8 \%$ for SBP and $9.3 \%$ for DBP with a net effectiveness of $8.5 \%$ and $2.4 \%$, respectively. The reduction of HBP by LSM was followed by increased aerobic conditioning and reduced intake of processed foods along with decreased values of BMI, abdominal fatness, insulin resistance, pro-inflammatory and peroxydative activities. Importantly, once applied nationwide this LSM would save HBP medication for 3.1 million of hypertensives at an economic saving costs of US\$ 1.47 billion a year! 


\section{HUMAN HYPERTENSION}

\section{Importance and epidemiology}

In $2000,26.4 \%$ of the adult world population (972 million) had hypertension, defined as BP $\geq 140 / 90 \mathrm{mmHg}$ or current use of antihypertensive medication, and $29.2 \%$ were projected to be hypertensive by 2025 [1]. High blood pressure (BP) is a strong, consistent, continuous, independent, and etiologically relevant risk factor for cardiovascular and therefore, the leading cause of preventable deaths worldwide $[2,3]$.

The prevalence of hypertension increases with age, with the estimated lifetime risk for elderly subjects reaching 90\% [4]. No evidence of a BP threshold exists therefore, the risk of cardiovascular disease increases progressively throughout the range of BP, including the pre-hypertensive range [5]. It has been estimated that almost a third of BP-related deaths from coronary heart disease occur in individuals with BP in the nonhypertensive range [6].

Hypertension has become a growing public health concern, particularly in developing countries, with an estimated prevalence of $37.3 \%$, in comparison with $22.9 \%$ in industrialized nations [7]. Projections are that by the year of $2025,75.0 \%$ (or 1.17 billion people) of the people with hypertension in the world will be living in emerging nations [8]. Studies estimate about one-third of the population in Latin America is affected by Blood Hypertension. Baseline findings (2014) from ELSA-Brasil show a frequency of 35.8\% high blood pressure [9].

\section{Social and economic impacts}

Hypertension has high medical and social costs, primary due to its many associated complications which lead to more severe cardiovascular disease, mortality, morbidity, incapacity and the use of medical services worldwide, factors that create high costs [10]. Treatment of blood hypertension (BP) and its associated complications among North Americans had an estimate cost of U\$ 37.2 billion (in 2003), with medications representing $47.8 \%$ of the estimated direct total expenses for health care in the US, an increase of $14 \%$ over the previous year (2002) [11].

In Brazil, the cost of medication spent with either one (US\$ 87.10), two (US\$ 159.00 ) or three (US\$ 194.00) drugs averaged US\$39.50/month for each diagnosed hypertensive subject [12]. Moreover, the estimated direct cost of Hypertension treatment in this country is 1.46 times higher in public than the private system. Together they represented $0.08 \%$ of the GDP (in 2005), or $1.11 \%$ of overall health care costs [13].

\section{Primary care by the brazilian public health system}

The Brazilian Public Health System is free and universal that intends to provide health care free of charge to its whole population. Since 1990 it has been organized by the Unified Health System (SUS-Sistema Unico de Saude) while the free distribution of medicines began in 1971. Free distribution of more than 15 medications for HyPERtension and DIAbetes (HIPERDIA program) clearly shows the important role of drugs in the Brazilian Government's effort to tackle these two diseases.

The governmental fueling of pharmaceutical-care expansion speeded up mostly in this century with the creation of programs aiming at increasing access to lowcost essential medications ("Farmacia Popular"-Popular Pharmacy Program) as a partnership between the federal government and states/municipalities. Later on, this strategy was expanded to include private pharmacies and drug stores, named "Aqui tem Farmacia Popular" (Popular Pharmacy is Available Here) began subsidizing 90\% of the reference price of 24 medicines, including those for hypertension and diabetes. In 2011, the government launched another program called "Saúde não tem preço" 
(Health has no price) to expand even more the access to medicines for diabetes and hypertension. In this program, the pharmacies and drug stores linked to the Popular Pharmacy network (more than 17,500) started to offer free medicines for the treatment of hypertension and diabetes.

\section{Effectiveness Of HIPERDIA Program}

Data sources on HiperDia Program are controlled mostly by the Ministry of Health and the available data are fragmentary and often outdated. When looking at the effectiveness scale it is unquestionable that prevalence of diabetes and hypertension are rising in parallel with that of excess weight as main NCDs burden in Brazil. In fact, from 2006 to 2010, according to VIGITEL, the self-reported prevalence of diabetes increased $5.3 \%$ in 2006 to $6.3 \%$ in 2010 , leading to an approximate $20 \%$ increase. Hypertension is estimated to present a $60 \%$ increase by the year 2025 . Thus seems that besides onerous, the SUS care of HyPERtension and DIAbetes has been demonstrated not quite effective.

Because drug therapy has been largely unsuccessful in halting and reversing the hypertension epidemic, it may be argued that more emphasis must be placed on novel approaches to enhance current primary prevention guidelines. Overall, it is known the prevalence of hypertension is rising in parallel with that of other NCDs and these increases are associated with unfavorable changes seen in our environment [14].

\section{THE EPIGENETICS}

\section{The thriftiness of body fluid conservation}

Our ancestors were often faced with survival stresses, including famine, infection, trauma and physical stress [15]. With the hot and humid climate, like in eastern Africa, effective heat dissipation is essential in hot environments and is achieved most efficiently through evaporative heat loss [16]. However, sweating due to the hot climate and excessive labor activities can lead to a large loss in the amount of salt and water, and eventually lead to hypovolemia, a threat to human survival. In addition, human and nonhuman primates living in ancient times had very low salt intake available. Low salt intake and large salt losses due to sweating had created robust salt appetite and renal sodium conservation, which were essential to survival [17].

Water loss and sodium deprivation due to insufficient sodium intake or excess sodium loss may activate rennin-angiotensin-aldosterone system, sympathetic nerve or neuroendocrine system to preserve sodium. The accumulation of sodium in tissue is accompanied by a commensurate retention of water to maintain the isotonicity of body fluids [17]. And, consequently, maintaining blood pressure [18].

Moreover, by facing infection, trauma and physical stress [15], there was an activation of the innate and adaptive immune system and, the acute inflammatory episode may cause water loss. To cope with the injury responses, a coordination of neuroendocrine, energy storage, water economy and immune systems are adapted. In fact, immune system plays the role in the regulation of sodium and water homeostasis $[19,20]$. Immune cells, such as mononuclear phagocyte system and macrophages, are responsible for interstitial hypertonic sodium retention, resulting from high salt diet intake, and stimulate lymph-capillary network formation. Notably, neoformed vessels (angiogenesis) in skin may serve as an extra sodium and water storage to buffer extracellular volume expansion and maintenance of blood pressure homeostasis. Moreover, inflammatory cytokines released from activated immune cells inhibits insulin signaling pathway; as a result, plasma levels of glucose are elevated to provide energy sources to maintain the function of vital organs (heart, brain and immune cells) and combat for the infection [21,22]. Additionally, to its metabolic effects, insulin induces vasorelaxation and regulates sodium homeostasis by enhancing sodium reabsorption in the kidney, thereby, contributing to the regulation of blood pressure $[17,23]$. 
The increased blood pressure by insulin resistance may contribute to increased blood perfusion to the brain during starvation and infection, and to the fetus during pregnancy [24].Therefore, negative regulation of insulin signaling could be viewed as a physiologic 'adaptive mechanism" that is activated in certain conditions such as fasting, inflammation, stress and pregnancy $[17,23]$.

It is well accepted that evolution by natural selection is a central organizing concept in biology and natural selection shapes organisms in functioning within a particular set of environmental conditions [25].

For millions of years, living creatures from lower-level organisms to human beings have been faced with stresses. Because organisms adapt to the totality of their environment, or ecological niche, it is hypothetically possible that natural selection favors organisms harboring the genotype for a metabolic system [17].

Since regulation of energy storage and the preservation of body fluids are critical for organism's fight against famine, infection and physical stress, it has been hypothesized that genes responsible for energy regulation and sodium preservation have been positively selected [26].

Hence, as results of natural selection, the survival pressures drove our evolution to shape a thrifty genotype, which favored/promoted energy-saving and sodium/water preservation [26].

The notion of thrifty genotype was initially proposed in which certain genotypes were selected into the human genome because of their selective advantage over the less thrifty genes. A thrifty genotype was originally defined as "being exceptionally efficient in the intake and/or utilization of food" [27].

Furthermore, the thrifty gene hypothesis postulates that under conditions of suboptimal in utero nutrition, the fetus must adapt to its environment to ensure survival of the organism, through a "sparing" of vital organs such as the brain at the expense of organs such as pancreas, kidney and skeletal muscle [28].

Therefore, thrifty phenotype represents a short-term (in-utero) adaptive response (preserving vital organs at the expense of less essential traits) to poor energy availability [29].

However, for doing it so, it was proposed that metabolic programming occurs to promote nutrient storage to provide a survival advantage in conditions of poor post natal nutrition [28].

Consequently, these adaptations can lead to the postnatal development of abnormalities such as obesity, glucose intolerance, hypertension and, metabolic syndrome in conditions of adequate nutrition or overnutrition [30-32].

\section{The linkage dietary transition and hypertension}

During the Paleolithic-neolithic interval (more than 2-million year), culminating in the emergence of today's sole Homo species, our ancestors lived as hunter-gatherers, eating wild animal-source foods (lean meats, internal organs, bone marrow, but no dairy) and uncultivated plant-source foods (mostly fruits, non-grain, vegetables, nuts, but no legumes) [33].

The contemporary western diet differs from paleolithic- type diets not only as a consequence of the agricultural and husbandry revolutions, but also as a consequence of the industrial revolution and, more recently, the fast food revolution. These revolutions have introduced foods that were absent or negligible in the paleolithic diet: refined cereal grains and their products, nonhuman mammalian milk and its 
products, energy-dense nutrient-poor foods (refined carbohydrates of wide variety, readily available and inexpensive; separated fats and oils of wide variety also) and legumes [34]. Other recognized dietary consequences of the three 'revolutions' include a reduction in the consumption of lean animal-source protein and a great increase in the consumption of sodium chloride and a decrease in potassium salts of organic acids $[35,36]$.

It has been argued that a discordance between our contemporary diets and the paleolithic-type diets to which evolutionary forces adapted our core metabolism and physiology over a period of millions of years of hominin evolution contributes in a major or critical way to the pathogenesis of the so-called diseases of civilization [34].

Hence, evidence suggests that genetic susceptibility to hypertension is ancestral. The evolution of hypertension susceptibility has been hypothesized to begin in Africa and, with the switch to a sedentary lifestyle and sodium- and energy-rich diets (current obesogenic environment), the thrifty genotype and ancient frugal alleles, are no longer advantageous, and may be maladaptive to disease phenotype, resulting in hypertension, obesity and insulin resistance syndrome.

At least two genes: angiotensinogen (AGT) and the epithelial sodium channel $\gamma$ subunit $(\mathrm{ENaC} \gamma)$, are involved in the regulation of sodium and blood pressure homeostasis [37]. However, this natural selection of thrifty genotype, which was a physiological adaptive mechanism for human survival, on the current environment, is maladaptive to disease phenotype $[15,17,38,24]$. Hypertension comes out as a mismatch between our ancestral genome with the current western lifestyle. Saltsensitive hypertension sodium-conserving (thrifty) genotype may be maladaptive to the modern environment of sodium abundance [26].

Thus, as humans evolve, the thrifty genotype for high cytokine responder (eradication of injury), mild insulin resistance (protection against starvation), or sodium preservation (maintenance of body fluid), which favored our ancestors, aiding them in the survival of critical conditions, may be positively selected, which may be maladaptive to our current, modern lifestyle, resulting in insulin resistance, hypertension, type II diabetes and cardiovascular diseases [24,29].

\section{The linkage obesity and inflammation}

Our ancestors (primitive humans) had to undertake considerable physical activity to gain food and had to adapt to prolonged period of famine, which favored fat storage, a trail inherited by modern man [39]. Nevertheless, in our modern lifestyle, characterized by energy-rich Western diet, sedentary life and high psychosocial stress, favors positive energy balance [30].

In the long term, this positive energy balance creates the need for surplus fat storage [40]. When the capacity for safe lipid storage in adipose tissue is exceeded lipids overflow to non-adipose tissue, increasing the risk for chronic systemic low grade inflammation [15,41]. Additionally, excess nutrient intake can induce oxidative stress in the adipose tissue. Oxidative stress conversely exerts significant effects on adipose tissue biology and can lead to dysregulation of adipocyte function, which manifests as inhibited adipocyte differentiation, enhanced immune cell infiltration into adipocytes and increased inflammatory cytokine secretion $[42,43]$.

Obesity-induced inflammation is associated with increased adipose tissue macrophage (ATM) infiltration [44,45]. Similar to a pathogenic response to an invading bacterium, excess nutrients found in the obese adipose microenvironment can lead to the pro-inflammatory activation and phenotypic switch (from M2 resident to M1 inflammatory macrophage) of macrophage [46]. 
A feature of obesity-associated ATM infiltration is the linkage of the induction of a chronic inflammation in White Adipose Tissue (WAT) [44]. Excess WAT is an overactive endocrine organ secreting an array of inflammatory adipokines, such as tumor necrosis factor $(\mathrm{TNF} \alpha)$, monocyte attractant protein $1(\mathrm{MCP}-1)$ and interleukin 6 (IL-6) [46].

\section{The linkage inflammation and insulin resistance}

The inflammatory cytokines can not only induce a chronic inflammatory process in adipocyte tissue, but also be released into circulatory blood, inhibiting insulin signaling; resulting in global insulin resistance [47]. The mechanisms impairing the biological effects of insulin could involve either serine/threonine kinase activation or an interaction between suppressor of cytokine signaling (SOCS) proteins and the insulin receptor. This could prevent its interaction with the insulin receptor beta subunit and the insulin signalizing pathway. In obesity the serine/threonine inhibitory phosphorylation by the fatty acids, pro-inflammatory cytokines and reactive oxygen species are mediated through specific intracellular signaling pathways involving C-Jun NH2 Terminal Kinase (JNK), Activating Protein-1 (AP- 1), nuclear factor kappa beta (NF-kB) and IkB kinase (IKK) signaling molecules [48].

Hence, chronic inflammation in obesity plays a critical role in pathogenesis of insulin resistance [47]. As obesity, insulin resistance and hypertension are considered to be Western diseases [49].

\section{The linkage insulin resistance and hypertension}

In human evolutionary history, insulin resistance may be an essential part of normal homeostasis to facilitate redirection of nutrients to pivotal organs and a physiological adaptive mechanism to promote our ancestor's survival in times of critical conditions. $[38,15]$. However, clinical and epidemiologic evidences demonstrate a close linkage between insulin resistance and hypertension. About $50 \%$ of hypertensive individuals have hyperinsulinemia or glucose intolerance, whereas up to $80 \%$ of patients with type 2 diabetes have hypertension [50]. The coexistence of insulin resistance and hypertension results in a substantial increase in the risk of developing cardiovascular disease and type II diabetes [24,29].

Hypertension is associated with increased systemic and vascular inflammatory responses and oxidative stress, which may contribute to vascular dysfunction and, insulin has complex vascular actions that appear as either vascular protective or deleterious effects. In physiological condition insulin stimulates endothelial NO production to exert a vasorelaxation and anti-inflammatory effect. Whereas, in the state of insulin resistance, the insulin- stimulated NO pathway is selectively impaired and the compensatory hyperinsulinemia may activate MAPK pathway, resulting in enhancement of vasoconstriction, pro- inflammation, increased sodium and water retention and the elevation of blood pressure [51]. Hence, vascular deleterious effects of insulin resistance include induction of vasoconstriction and pro-inflammatory activity. Insulin can be both inflammatory and anti-inflammatory [52]. Underlying the mechanisms is complex and may involve a low grade chronic inflammation and oxidative stress [42].

Some hormones that mediate water retention such as angiotensin II and aldosterone are also endowed with pro-inflammatory effects, and has an important role in the pathogenesis of hypertensive and metabolic diseases. Insulin increases sodium reabsorption in the kidney and promotes sympathetic nerve activity [17]. Hypertensive patients with salt sensitivity are more insulin resistant than those with salt-resistance. Furthermore, high salt diet impairs insulin sensitivity only in hypertensive patients with salt- sensitivity but not in those with salt-resistance, suggesting that there is a pathogenetic link among hypertension, salt- sensitivity and insulin resistance. 


\section{The metabolic syndrome}

As our civilization evolved, a sedentary lifestyle and sodium- and energy-rich diet, the thrifty genotype is no longer advantageous, and may be maladaptive to disease phenotype [17]. In fact, the same mechanism may be inappropriately activated on a chronic basis on the current obesogenic environment, leading to abdominal adiposity, insulin resistance and hypertension which are the components of metabolic syndrome and often coexist [50]. Hence, the metabolic syndrome is not a single disease, but a complex cluster of symptoms that include a large waist circumference, hypertension, hyperglycemia and dyslipidemia [40].

Since patients with metabolic syndrome are commonly afflicted with cardiovascular morbidities, the metabolic syndrome and cardiovascular diseases share common pathways including increased oxidative stress, defective glucose and lipid metabolism, low-grade inflammation, hypercoagulability and endothelial damage. Some investigators have proposed to use the "circulatory syndrome" to refine the metabolic syndrome concept through the addition of markers of cardiovascular diseases such as renal impairment, micro-albuminuria, arterial stiffness and left ventricular dysfunction [32].

\section{NON-DRUG CARE}

Elevated BP results from environmental factors, genetic factors, and interactions among these factors [53]. It has become clear that most, if not all, typically Western chronic diseases find their primary causes in unhealthy lifestyles and that systemic low -grade inflammation is a common denominator. The epigenetics studies point out the prevalence of hypertension as perpetrated by lifestyle factors, such as consumption of high fat and/or high-salt diets and physical inactivity. Hence, alternatively to medicine drugs, lifestyle and behavioral modifications are stressed for the prevention, treatment, and control of hypertension. These include weight loss, moderation of alcohol intake, a diet with increased fresh fruits and vegetables, reduced saturated fat, reduced saltintake and, increased physical activity $[5,54]$.

\section{Physical exercises}

Physical inactivity and overweight are common characteristics in Western societies and therefore, lifestyle interventions in the form of physical exercises and nutritional education (dietary advice) have been recommended by the American College of Sports Medicine (ACSM) since 2000 and accepted by almost all NCD-related Societies. In November of 2007 ACSM launched the "Exercise is Medicine" (EIM) initiative but, only in April 2011, the Brazilian government launched the Health Gym Program created in order to promote physical activity and provide free-of-charge spaces and support for living a healthy lifestyle.

\section{Interventions with physical exercises}

Two meta-analyses have demonstrated the beneficial effects of exercise on blood pressure. The first analysis showed that walking reduced resting systolic and diastolic blood pressure in adults by an average of $3 \mathrm{mmHg}$. In the second, in 54 randomized clinical trials, aerobic exercise reduced systolic blood pressure an average of $4 \mathrm{mmHg}$ and diastolic blood pressure $2 \mathrm{mmHg}$, irrespective of changes in body weight. Thus, increasing the amount of low- to moderate-intensity physical activity to 30-45 minutes most days of the week is an important adjunct to other lifestyle strategies $[55,56]$.

For lowering blood pressure guidelines recommend predominantly aerobic exercises such as walking, jogging and cycling. However a body of research is emerging that show resistance training may also beneficially affect metabolic health [57-59]. An exercise frequency of 3 days per week has been considered to be the minimal frequency 
for $\mathrm{BP}$ reduction and exercising more times at a low intensity may be more effective than more intense training performed less than 3 times per week in order to reduce blood pressure [60].

\section{Mechanisms of lowering blood hypertension by physical exercise}

Exercise has the most potent effect on endothelium-dependent vasodilatation and, the endothelium -derived nitric oxide (eNO) is thought to be necessary to maintain an adequate vascular response to increased blood-flow demands during exercise. Shear stress is an important component of exercise, and it affects vascular NO concentration, and increases the velocity of the endothelial high-affinity/low-capacity transport system for L-arginine [61]. This ensures substrate availability, as the ratelimiting step of eNOS, which generates ROS in the absence of L-arginine [62]. Muscular contraction dependent $\left[\mathrm{Ca}^{++}\right]$also modulates eNOS activity but shear stress lead to eNOS phosphorylation on serine residues independent from increases in $\left[\mathrm{Ca}^{++}\right]$[63]. However, it has long been enigmatic how exercise training that increases total oxygen uptake and in turn, the production of ROS, can improve endothelial- derived NO, considering that it increases also the expression of ecSOD, in vascular smooth muscle cells? $[64,65]$.

It was demonstrated that exercise training really increases both eNOS and ecSOD expression hence, alternating the premature breakdown of NO by ROS [62]. Thus, exercise training may correct endothelium-dependent vasodilatation by a variety of mechanisms. First, shear stress augments the expression of nitric oxide synthase in endothelial cells. Second, shear stress induces up-regulation of the cytosolic copperand-zinc containing superoxide dismutase, a free-radical scavenger. The inactivation of nitric oxide by a vascular superoxide or other reactive oxygen species may thereby be attenuated. Third, shear-stress-mediated suppression of angiotensin-converting enzyme may influence endothelium- dependent relaxation by affecting local concentration of bradykinin by keeping it active [66].

\section{DIET}

The contemporary American diet figures centrally in the pathogenesis of numerous chronic 'diseases of civilization' and, a substantial body of evidence strongly supports the concept that multiple dietary factors affect blood pressure (BP). In fact, of the environmental factors that affect BP (diet, physical inactivity, toxins, and psychosocial factors), dietary factors have a prominent, and likely predominant, role in BP homeostasis. Healthful lifestyle is a critical component of hypertension reduction strategies, and diet is the lifestyle factor with the strongest effects on BP.

In non-hypertensive individuals, including those with pre-hypertension, dietary changes that lower BP have the potential to prevent hypertension and more broadly to reduce BP and thereby lower the risk of BP-related clinical complications. Furthermore, in uncomplicated stage I hypertension, dietary changes serve as initial treatment before drug therapy. Among hypertensive individuals who are already on drug therapy, dietary changes, particularly a reduced salt intake, can further lower BP and facilitate medication step-down. In general, the extent of BP reduction from dietary therapies is greater in hypertensive than in non-hypertensive individuals. Established dietary modifications that effectively lower BP are weight loss, reduced sodium and increased potassium intake, reduction in excessive alcohol consumption, and vegetarian and dietary approaches to stop hypertension (DASH)-type dietary patterns $[67,68]$.

The original Dietary Approaches to Stop Hypertension (DASH) trial demonstrated that a diet that emphasizes fruits, vegetables, and low-fat dairy products, that includes whole grains, poultry, fish, and nuts, that contains only small amounts of red meat, sweets, and sugar-containing beverages, and that contains decreased amounts of total 
and saturated fat and cholesterol lowers blood pressure substantially both in people with hypertension and those without hypertension, as compared with a typical diet in the United States [69].

The original DASH diet combined increased intake of fruits, vegetables, and low-fat dairy products with a relatively low intake of total and saturated fat, and a subsequent version incorporated sodium restriction to further enhance BP reduction $[69,70]$.

Furtheron, the Omni Heart feeding study documented that in the setting of a healthy diet similar to the DASH diet, partial substitution of carbohydrate with either protein (about half from plant sources) or monounsaturated fat lowers BP [71]. The traditional Mediterranean diet (MedDiet), a plant- based dietary pattern high in MUFA because of the customary use of olive oil, shares many constituents with DASH-type diets, especially with the high-MUFA Omni-Heart diet. Increased adherence to the MedDiet was associated with reduced BP in EPIC (Greek) and SUN (Spain) studies [72,73].

The paleolithic-type diet showed similar BP effects to the DASH low-sodium diet, and better lipid profiles than the Omni- Heart diets (high-carbohydrate from fruits and vegetables; high-protein from animal-source foods; high- unsaturated fats) [70,71,].

A distinction between Paleolithic nutrition and other diets (including low carbohydrate ones) that may contribute to its health benefits is the fact that it exclusively comprises non- processed foods. Food-processing procedures often entail the addition of salt. Compared with their usual diet, a short-term consumption of a paleolithic type diet improves BP and glucose tolerance, decreases insulin secretion, increases insulin sensitivity and improves lipid profiles without weight loss in healthy sedentary humans.

Many other diet regimens have been also reported to have benefits on BP. Several of them (for example, vegetarian and vegan diets) differ in many respects compared with paleolithic-type diets [36]. Several aspects of a vegetarian lifestyle might lower $\mathrm{BP}$, including non-dietary factors (eg, physical activity), established dietary risk factors (eg, reduced weight, increased potassium, and low-to-moderate alcohol intake), and other aspects of vegetarian diets (eg, high fiber, no meat) [53].

\section{Modulators of dietary effects}

Genetics - A rapidly increasing body of evidence indicates that genetic factors affect $\mathrm{BP}$ levels and the BP response to dietary changes. Most of the available evidence has focused on genetic factors that influence the BP response to salt intake. Most of these genotypes influence the renin-angiotensin- aldosterone axis or renal salt handling [53]. Six genes associated with higher BP and another 8 genes associated with lower BP have been identified [74]. It is noteworthy that each of these genes regulates renal sodium chloride handling; mutations that increase net sodium chloride reabsorption raise $\mathrm{BP}$, whereas mutations that reduce sodium chloride reabsorption lower BP [24].

Aging - Because of the age-related rise in BP that is particularly prominent in middle-aged and older people and because of their high prevalence of BP-related cardiovascular disease, dietary strategies should be especially beneficial as adults age [24]. Older people can make and sustain dietary changes, specifically weight loss and dietary sodium reduction, over the long term and, secondly, greater BP reductions from dietary interventions occur as individuals get older. [75-79].

Racial-On average, blacks have higher BP and are at greater risk of BP-related complications than non-blacks [80-82]. However, as documented, blacks as compared with non-blacks achieve greater BP reduction from several non-pharmacological therapies, specifically sodium reduction, increased potassium intake, and the DASH diet [53]. The potential benefits of these dietary approaches are amplified because 
survey data indicate that blacks consume high levels of sodium while their potassium intake is less than that of non-blacks [83].

\section{Combining lifestyle interventions}

The effects of lifestyle modifications are dose and time dependent and therefore can be greater for some individuals than others and, most encouraging are the trials implementing multiple lifestyle modifications and showing that combining lifestyle interventions can lower blood pressure more effectively than single approaches [84.].

Two trials evaluated the efficacy of implementing simultaneously multiple lifestyle modifications: sodium reduction, weight loss, the DASH diet, and regular physical activity $[85,86]$. The Diet, Exercise, and Weight Loss Intervention Trial randomized hypertensive participants to a lifestyle change or control group. At the end of the 9-week intervention, net reductions in 24-hour ambulatory systolic and diastolic blood pressure were 9.5 and $5.3 \mathrm{mmHg}$, respectively, and changes in daytime systolic and diastolic blood pressure were 12.1 and $6.6 \mathrm{mmHg}$, respectively[86]. In the PREMIER trial of hypertensive adults, multicomponent, behavioral interventions or multiple behavioral interventions plus DASH were compared to an "advice only" control group. In the multiple behavioral interventions plus DASH group, the mean net reduction in systolic blood pressure was $11.1 \mathrm{mmHg}$, and in diastolic blood pressure it was 6.4 mmHg. Both studies concluded that in people with hypertension, a comprehensive lifestyle intervention program can substantially lower blood pressure and reduce cardiovascular disease risk [86].

Thus, modest weight reduction, the DASH eating plan, sodium reduction, physical activity, and moderation in alcohol intake are effective in lowering blood pressure and preventing hypertension. However, combining these lifestyle interventions is more effective than single approaches.

Other lifestyle factors-potassium supplementation also can help control or prevent hypertension; dietary fiber, calcium, magnesium, and fish oil intakes, have been studied but have uncertain efficacy [84].

\section{Effectiveness of non-drug care}

The potential benefits of dietary changes are substantial for BP care either preventive or therapeutics irrespectively to gene polymorphism, racial or aging disparities. In participants with hypertension, the combined effects on blood pressure of a low sodium intake and the DASH diet were equal to or greater than those of singledrug therapy. It is estimated that a population-wide reduction in blood pressure comparable to that seen with the reduced sodium DASH diet would result in a decrease of $17 \%$ in the prevalence of hypertension, a $6 \%$ reduction in the risk of coronary heart disease, and a 15\% reduction in stroke and transient ischemic attacks [87].

In the Canadian Community Health Survey, reducing dietary sodium additives might decrease the hypertension prevalence by $30 \%$, resulting in one million fewer hypertensive patients in Canada, and almost double the treatment and control rate. Physician visits and laboratory costs would decrease by $6.5 \%$, and $23 \%$ fewer treated hypertensive patients would require medications for control of blood pressure. Direct cost savings related to fewer physician visits, laboratory tests and lower medication use are estimated to be approximately $\$ 430$ million per year [88].

\section{A COMMUNITY-BASED EXPERIENCE}

\section{The CeMENutri's longitudinal study}

The program called "Move for Health" is an ongoing epidemiology study conducted, since 1991, by professionals linked to the Metabolism Exercise and Nutrition Center (CeMENutri) at UNESP Medical School (Botucatu city, Sao Paulo state, Brazil). As a 
community based project it includes adult ( $>35$ yrs old) participants from both genders that come to the clinic for preventive health examination and further interventions involving nutrition reeducation, supervised physical exercise and other lifestyle factors associated with increasing risk for chronic diseases. They come to the clinic spontaneously or by either a friend or doctor indication looking for preventive health examination with further non-medicated interventions.

Upon registration and accomplishing ethical requirements the subjects are submitted to multi professional assessments for clinical, anthropometric, dietary, physical activity, blood analysis, fitness (aerobic, strength and flexibility), and postural. From these baseline assessments the participants are able to choose followup interventions involving supervised exercises combined with weekly counseled (or supervised) dietary interventions(LSM program). The physical exercise protocol is composed by daily sessions of $100 \mathrm{~min}, 3-5 \mathrm{x} / \mathrm{wk}$, including $20 \mathrm{~min}$ warm up/ stretching, 30 min walking (60-80\% $\mathrm{VO}_{2 \text { max }}$ ), 40 min strength in academy (3x 8-12 rep, 60-70\% $1 \mathrm{RM}$ ) and 10min stretching and cool down. The follow-up assessments occur every 10 weeks. The assessments as well as physical exercises and dietary interventions are conducted by graduate students holding institutional fellowships linked to CeMENutri. The program is opened for beginners three times a year and is free of charge for the first 10 weeks.

\section{Hypertension trial}

An initial medical screening is carried out to exclude those individuals with severe hypertension, diabetes mellitus, cardiopulmonary, renal, hepatic, and severe orthopedic diseases. Resting blood pressure (BP) is measured using a digital automatic oscillometric device (Omron, USA). As published earlier, these measurements were superimposed to parallel measurements taken with a standard mercury manometer in the initial screening period and, there were no significant intra-and inter-device reading deviation [48].

\section{Cross-sectional data}

Data from 1317 subjects enrolled during the period of 2006 to 2016 showed that top quartile of $\operatorname{SBP}\left(>_{-} 142.2 \mathrm{mmHg}\right)$ differed from the lower quartile $\left(<_{-} 120.6 \mathrm{mmHg}\right)$ by variables related to demographic, socioeconomic, nutritional, physical activity and fitness, antropometric and blood chemistry aspects (Tables 1 and 3). Similarly,P75(<_88.5mmHg) differed from P25(<_69.2mmHg) for DBP (Tables 2 and 4).

\section{Demographic and socioeconomic}

Tables 1 and 2 show the top quartile of SBP and DBP, respectively, as older presenting lower schooling, lower income and similarly in gender, than the lower quartile. Oftenly, aging is referred as causing fator for blood hypertension [24]. whereas the socieconomic characteristics of lower schooling and low income might be peculiar to our sample. The effect of family-income status might be minimized because in Brazil, the medication for hypertension is free of charge.

\section{Dietetic}

The dietetic data presented in table 3 and 4 show that top quartile of SBP and DBP, respectively, are similar in energy intake but higher in the amount of CHO and saturated fat than the lower quartile. Additionally, the top quartile presented a lower quality diet (HEI), similar in fiber, calcium and potassium but higher in sodium. The characteristics of ingesting a more processed food by the higher SBP subjects was identified by their higher ratios of CHO/Fiber (sugar intake), sodium/potassium and saturated fat/MUFA. Higher DBP lacked to present the higher saturated fat/MUFA ratio (Table 4). As referred earlier, dietary quality is a strong determinant of blood hypertension [53]. 


\begin{tabular}{|c|c|c|c|}
\hline & \multicolumn{3}{|c|}{ Systolic Blood Pressure $(\mathrm{mmHg})$} \\
\hline & $\leq \mathrm{p} 25$ & $\geq \mathrm{p} 75$ & \\
\hline & $\leq 120.60$ & $\geq 142.20$ & \\
\hline Parameters & $\mathrm{n}=296$ & $n=298$ & $\mathrm{p}$ \\
\hline Age-md(min-max) & $52.00(34.00-84.00)$ & $60.00(35.00-79.00)$ & 0.04 \\
\hline \multicolumn{4}{|l|}{ Gender } \\
\hline Female (n/\%) & $221(48.7)$ & $233(51.3)$ & 0.81 \\
\hline Male $(n / \%)$ & $75(53.6)$ & $65(46.4)$ & 0.79 \\
\hline \multicolumn{4}{|l|}{ Schooling } \\
\hline Uncompleted Elementary Grade (n/\%) & $1(7.2)$ & $13(92.8)$ & 0.01 \\
\hline Completed Elementary Grade (n/\%) & $52(32.5)$ & $108(67.5)$ & 0.04 \\
\hline Completed High School (n/\%) & $150(58.6)$ & $106(41.4)$ & 0.16 \\
\hline Completed College (n/\%) & $93(56.7)$ & $71(43.3)$ & 0.59 \\
\hline \multicolumn{4}{|l|}{ Family Income (minimum wage) } \\
\hline$\leq 2(n / \%)$ & $9(32.1)$ & $19(67.9)$ & 0.38 \\
\hline 2 to $5(n / \%)$ & $39(22.1)$ & $137(77.9)$ & 0.04 \\
\hline 5 to $10(n / \%)$ & $141(62.4)$ & $85(37.6)$ & 0.43 \\
\hline$>10(n / \%)$ & $107(65.2)$ & $57(34.8)$ & 0.03 \\
\hline
\end{tabular}

\begin{tabular}{|c|c|c|c|}
\hline & \multicolumn{3}{|c|}{ Diastolic Blood Pressure (mmHg) } \\
\hline & $\leq \mathrm{p} 25$ & $\geq \mathrm{p} 75$ & \\
\hline & $\leq 69.20$ & $\geq 88.50$ & \\
\hline Parameters & $\mathrm{n}=297$ & $\mathrm{n}=295$ & $\mathrm{p}$ \\
\hline Age-md(min-max) & $52.10(34.00-76.00)$ & $\begin{array}{l}57.60(35.00- \\
79.00)\end{array}$ & 0.07 \\
\hline \multicolumn{4}{|l|}{ Gender } \\
\hline Female $(n / \%)$ & $213(48.7)$ & $224(51.3)$ & 0.83 \\
\hline Male (n/\%) & $84(54.2)$ & $71(45.8)$ & 0.67 \\
\hline \multicolumn{4}{|l|}{ Schooling } \\
\hline $\begin{array}{l}\text { Uncompleted Elementary Grade } \\
\qquad(\mathrm{n} / \%)\end{array}$ & $6(24.0)$ & $19(76.0)$ & 0.001 \\
\hline Completed Elementary Grade (n/\%) & $49(26.4)$ & $137(73.6)$ & 0.004 \\
\hline Completed High School (n/\%) & $127(55.9)$ & $100(44.1)$ & 0.71 \\
\hline Completed College (n/\%) & $115(74.7)$ & $39(25.3)$ & 0.002 \\
\hline \multicolumn{4}{|l|}{ Family Income (minimum wage) } \\
\hline$\leq 2(n / \%)$ & $14(40.0)$ & $21(60.0)$ & 0.38 \\
\hline 2 to $5(n / \%)$ & $57(28.3)$ & $144(71.7)$ & 0.04 \\
\hline 5 to $10(n / \%)$ & $96(53.0)$ & $85(47.0)$ & 0.43 \\
\hline$>10(\mathrm{n} / \%)$ & $130(70.3)$ & $55(29.7)$ & 0.03 \\
\hline
\end{tabular}

Adult females and males, with essential arterial hypertension showed lower calcium intake than sex and age matched normotensive controls [89]. Further on, we had published that dietary variety with $\geq 8$ food items showed a protective effect for alterations in systolic blood pressure whereas it was found a positive relationship between diastolic blood pressure and sugar and cholesterol intake. On the other hand, there was a negative relationship of diastolic pressure with the intakes of fiber, portions of oil and fats and diet quality [90]. Overall, the present data showed higher blood pressure associated with a dietary characteristics of high "processed pattern" (high sodium, low potassium and calcium, high sugar, low fiber).

\section{Physical activity and fitness}

Tables 3 and 4 show the top quartile of BP presenting lower physical activity and aerobic capacity in the treadmill test. Sedentary behavior is one cause of blood hypertension in adults and, lower aerobic conditioning is a major consequence of low-regular physical activity. Besides presenting similar BMI the extremes quartiles of BP differed in the body fat content (Tables 3 and 4). The top quartile had higher fat 
The lifestyle modification effectiveness in reducing Hypertension in a Brazilian Community: From the epigenetic basis of Ancestral Survival to the Contemporary Lifestyle and Public Health Initiatives

Table 3: Food intake, dietary quality, anthropometric, physical fitness, biochemistry and clinical data for the opposite Systolic Blood Pressure quartiles.

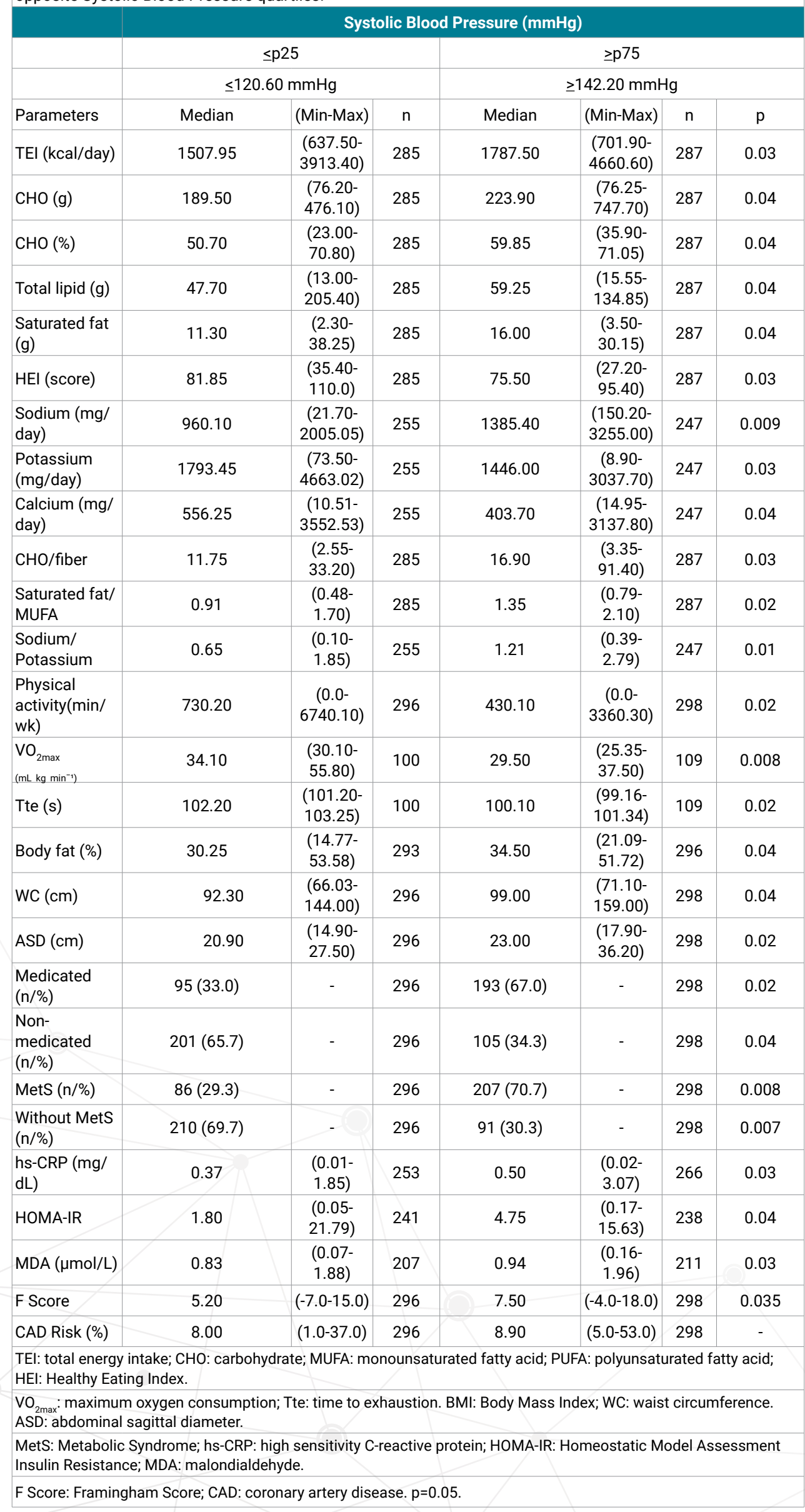


composition either in the whole body (\% body fat) as well as in the abdominal (WC and ASD). The higher \% body fat was presented only by SBP (Table 3).

\section{Anthropometric and clinical-biochemistry}

The similarity of BMI along with the TEI, irrespectively to the BP quartile reflect the bad nutritional condition of the whole sample. The presence or absence of metabolic syndrome did not affected the distribution of subjects in the top or lower quartile of BP (Tables 3 and 4). However, the top quartile of SBP was characterized by higher proinflammatory activity (levels of hs-CRP), insulin resistance (HOMA-IR) and systemic peroxidation (MDA levels). DBP differed from SBP by both quartiles presenting similar values of HOMA-IR and hs-CRP (Tables 3 and 4).

The Framingham score used to estimate the coronary artery disease (CAD) risk over the next 10 years, was significantly higher in P75 comparatively to P25, in both SBP and DBP. However, the calculated risk to develop CAD varied only by $0.9 \%$ (SBP) and 4\% (DBP), between the two quartiles (Tables 3 and 4).

\section{Medication and clinical efficiency}

The rate of undiagnosed patients for $\mathrm{BH}$ was $9.8 \%$ and, as expected, the top quartile presented higher proportion of medicated/non-medicated hypertensive patients $(3 / 1)$ for both SBP and DBP (Tables 3 and 4). The worldwide proportion between individuals with controlled and no controlled blood pressure is described by the literature as 1:2 [91]. Our proportion of medicated-controlled: medicated-non controlled BH was 2.47:1.

Our medical Institution conducts free of charge a specific program to attend all registered hypertensive subjects providing anti-hypertensive drugs. Thereby, it is hard to understand why $9.8 \%$ of the hypertensive patients were unawared of their abnormality (undiagnosed BP). Moreover, even more difficult it is to understand how $2 / 3$ of the medicated subjects still presented BH levels. Hence, it seems though, that anti-hypertensive drugs were not working reasonably and their users were not satisfied enough with this situation. Therefore, one might speculate the existence of an ongoing cultural resistance to the usual drug treatment and, an arising attention for alternative non-drug procedures. Based on this, the LSM intervention would be one of these alternatives. The medicated non-controlled patients would be those interested in the LSM alternative. In addition, the medicated non-controlled patients referred themself as being in excellent or good state of health (92\%) showing moderate status of physical activity (53\%) with $85.1 \%$ full filing the WHO's recommendations for being active individual.

Mostly of the medicated non-controlled patients were from the low-income range (less than US\$1,500 a month) and though probably under the Brazilian rules for free of charge medications. Excluding the economical reasons, the two other important points would be their self-perception of being in an excellent/good health status, meaning" I'm feeling good so I'm cured so I don't need medication anymore" and/or they were younger (60\% under $60 \mathrm{yrs}$ ) and physically active and (56.8\%) able for weekly moderate- activities. In the later instance, the patients probably realized the beneficial effects of being healthy without medicines (and their unpleasant side effects) and looked for the lifestyle modification alternative such as our LSM program.

\section{LONGITUDINAL DATA}

\section{Prevalence of Clinical Hypertension}

At baseline, the prevalence of systolic hypertension (>_140mmHG) in this freedemand sample was $51.2 \%$ and, $42.7 \%$ for diastolic (>_90mmHg). Studies estimate about one-third of the population in Latin America is affected by Blood Hypertension 
(Kearney et al. 2004). In Brazil, the estimated prevalence for the past three decades (according to the JNC criteria) was 31.0\% (Picon-14). In 2005, 28.5\% (33.6 million) of the Brazilian population over age 18 were considered hypertensive [92]. Three years before the distribution of hypertensive patients by the Brazilian guidelines varied from $53.3 \%$ stage 1 to $35.7 \%$ stage 2 and $11 \%$ stage 3. Baseline findings (2014) from ELSA-Brasil show a frequency of $35.8 \%$ high blood pressure [9]. Our data was obtained from subjects in spontaneous demand and therefore not representative of the general population. The free demand would probably explain why our higher prevalence, comparatively to the general population.

\section{Clinical Effectiveness of Lifestyle-Change Protocol}

Individuals were considered hypertensive when their systolic blood pressure (SBP) readings were persistently greater than or equal to $140 \mathrm{mmHg}$ and/or their diastolic blood pressure (DBP) readings were greater than or equal to $90 \mathrm{mmHg}$, according to at least two different readings over one or more weeks under standard conditions [10].

Ten weeks of LSM reduced the higher SBP(>_ $140 \mathrm{mmHg}$ ) from $51.2 \%$ at baseline to $33.4 \%$. The high $\mathrm{DBP}\left(>_{-} 90 \mathrm{mmHg}\right)$ reduction was from $42.7 \%$ to $33.4 \%$. Hence, the found 10wk-LSM effectiveness in normalizing hypertension was $17.8 \%$ for SBP and $9.3 \%$ for DBP. However, during the intervencion 9.3\% of SBP normotensives became hypertensive as well as $6.9 \%$ of DBP. Therefore, for the whole sample the net effectiveness of LSM was $8.5 \%$ for normalizing SBP and, 5.2\% for DBP.

The reduction of BP with LSM was followed by increasing the treadmill lenght and decreased intake of processed-food markers as well as a decreasing in BMI and abdominal fatness (WC and ASD ). The slimed body was probably the cause for reducting of pro-inflammatory,(hs-CRP) insulin resistance(HOMA-IR) and lipoperoxidation(MDA) activities seen with LSM(Table 5). Besides reducing significantly the Framingham score, the LSM impacted slightly on DAC risk by a $0.45 \%$ reduction (Table 5). Contributed to this negligible reduction of DAC risk by LSM, the fact our population had already a low risk $(<10 \%)$, at baseline [93].

The decreased intake of processed-food markers was determinant for hypertensive responders to our LSM. In participants with hypertension, the combined effects of a low sodium intake and the DASH diet were equal to or greater than those of singledrug therapy. It is estimated that a population-wide reduction in blood pressure comparable to that seen with the reduced sodium DASH diet would result in a decrease of $17 \%$ in the prevalence of hypertension [87]. In the Canadian Community Health Survey, reducing dietary sodium additives may decrease the hypertension prevalence by $30 \%$ [88].

\section{Economic Effectiveness of Lifestyle-Change Protocol}

In late august of 2015 the Brazilian population was estimated as 204 million and, according to the 2010 distribution, $75.9 \%$ were between 15 to 64 years of age and $7.4 \%$ over 65 years old (IBGE). Hence, one might consider half of the actual whole population as adult and, considered $35.8 \%$ of those over 35 yrs old as hypertensives [9], we would have 36.5 million Brazilian adults under BP treatment.

In Brazil, the cost of medication spent with either one (US\$ 87.10), two (US\$ 159.00 ) or three (US\$194.00) drugs averaging US\$39.50/month for each diagnosed hypertensive subject [12]. Figuring out the drug spending of US\$ 474 a year for each patient we will end up to the yearly sum of US $\$ 17.3$ billion spent with anti-hypertensive medications! Moreover, we found rates of medicated-non controlled hypertensives as $65.2 \%$ and $67 \%$ for diastolic and systolic BP, respectively. If applied nationwide, these rates would mean a wasting of more than US\$ 14 billion spent with medications that are not working properly! 
The effectiveness of our 10wk-LSM in normalizing SBP hypertension was $17.8 \%$ which discounting $9.3 \%$ of the normotensives that became hypertensive we come to the net effectiveness of our LSM as $8.5 \%$ for normalizing SBP. If applied nationwide this LSM would save BP medication for 3.1 million of hypertensives at an year economic costs of US\$ 1.47 billion! Our early publication involving only hypertensive nonmedicated men in a 8-month long LSM came to the estimated economic costs of US\$ 14.2 billion a year [10]. Therefore, our LSM drug-saving might be time dependent. The professional cost(with fellowships) of our LSM program is estimated at US\$ 900/mo. without considering indirect costs of laboratory tests and physical plant (gymnasium) use and conservation. Thus by saving the current drug-expending costs with BP, the alternative BP treatment given by the presented LSM could be settled down in mostly of the more than 5,555 Brazilian cities, mainly those provided by public medical schools either by public or private health systems.

\section{CONCLUSION}

Hypertension (HBP) has high medical and social costs with medications representing almost half of the estimated direct expenses and are free distributed by the Brazilian government. Notwithstanding this, the prevalence of HBP is rising in parallel with other NCDs. Hence, because drug therapy has been largely unsuccessful in halting and reversing the hypertension epidemic, it may be argued that more emphasis must be placed on novel approaches to enhance current primary prevention guidelines. HBP results from environmental and genetic factors, and interactions among them. Epigeneticaly HBP results from the mismatch of our ancestral thrifty genotype which favored/promoted energy-saving and sodium/water preservation, with a contemporary sodium- and energy-rich diets and sedentary lifestyle environment. Therefore, alternatively to medicine drugs, lifestyle and behavioral modifications are stressed for the prevention, treatment, and control of hypertension. A lifestyle modification program (LSM) involving dietary counseling and regularly supervised physical activity ("Move for Health"-LSM) is used in our group for decades for NCDs primary care. Ten weeks of LSM effectively reduced HBP to normal in $8.5 \%$ of systolic and $5.2 \%$ of diastolic HBP. In 8-mo. LSM the achieved effectiveness was 38\%. Once applied nationwide this LSM figures would save HBP medications for 3.1 million of hypertensives at an economic costs of US\$1.47 billion a year!

\section{ACKNOWLEDGEMENTS}

CNPq (RCB fellowship), FAPESP (laboratory equipment supply) and CAPES (HTK and CNMN fellowships).

\section{REFERENCES}

1. Kearney PM, Whelton M, Reynolds K, Muntner P, Whelton PK, et al. Global burden of hypertension: analysis of worldwide data. Lancet. 2005; 365: 217-223. Ref.: https://goo.gl/OduA7o

2. Whitworth JA. World Health Organization, International Society of Hypertension Writing Group. 2003 World Health Organization (WHO)/ International Society of Hypertension (ISH) statement on management of hypertension. J Hypertens. 2003; 21:1983-1992. Ref.: https://goo.gl/YpjuoH

3. Ezzati M, Lopez AD, Rodgers A, Vander Hoorn S, Murray CJ. Comparative Risk Assessment Collaborating Group. Selected major risk factors and global and regional burden of disease. Lancet. 2002; 360: 1347-1360. Ref.: https://goo.gl/iOBu3U

4. Vasan RS, Beiser A, Seshadri S, Larson MG, Kannel WB, et al. Residual lifetime risk for developing hypertension in middle-aged women and men: The Framingham Heart Study. JAMA. 2002; 287:1003-1010. Ref.: https://goo.gl/C3dkjA

5. Lewington S, Clarke R, Qizilbash N, Peto R, Collins R. Age-specific relevance of usual blood pressure to vascular mortality: a meta-analysis of individual data for one million adults in 61 prospective studies. Lancet. 2002; 360: 1903-1913. Ref.: https://goo.gl/Nm32SP

6. Stamler J, Stamler R, Neaton JD. Blood pressure, systolic and dia- stolic, and cardiovascular risks: US population data. Arch Intern Med. 1993; 153: 598-615. Ref.: https://goo.gl/TGsWvn 
7. Picon RV, Fuchs FD, Moreira LB, Riegel G, Fuchs SC. Trends in Prevalence of Hypertension in Brazil: A Systematic Review with Meta-Analysis. PLoS ONE. 2012; 7: e48255. Ref.: https://goo.gl/fl0ZKM

8. Kearney PM, Whelton M, Reynolds K, Whelton PK, He J. Worldwide prevalence of hypertension: a systematic review, J Hypertens. 2004; 22: 11-19. Ref.: https://goo.gl/q6T2pc

9. Schmidt MI, Duncan BB, Mill JG, Lotufo PA, Chor D, et al. Cohort Profile: Longitudinal Study of Adult Health (ELSA-Brasil). Int J Epidemiol. 2015; 68-75. Ref.: https://goo.gl/ooYsZp

10. Burini RC, Simonetti LA, Maesta N, Waib PH. Efficiency and Cost less of a Long-term Physical Exercise Program to Non-medicated Hypertensive Males. Advanced Studies in Medical Sciences. 2013; 1: 111-123. Ref.: https://goo.gl/80WAEp

11. Thom T, Haase N, Rosamond W, Howard VJ, Rumsfeld J, et al. Heart disease and stroke statistics--2006 update: a report from the American Heart Association Statistics Committee and Stroke Statistics Subcommittee. Circulation. 2006; 113: e85-151. Ref.: https://goo.gl/8mRxgt

12. Moreira GC, Cipullo JP, Martin JF, Ciorlia LA, Godoy MR, et al. Evaluation of the awareness, control and cost-effectiveness of hypertension treatment in a Brazilian city: populational study. $J$ Hypertens. 2009; 27: 1900-1907. Ref.: https://goo.gl/1gRtyO

13. Dib MW, Riera R, Ferraz MB. Estimated annual cost of arterial hypertension treatment in Brazil. Rev Panam Salud Publica. 2010; 27: 125-131. Ref.: https://goo.gl/y3jH5n

14. Schmidt MI, Duncan BB, Silva GA, Menezes AN, Monteiro CA, et al. Chronic non-communicable diseases in Brazil: burden and current challenges. Lancet. 2011; 377: 1949-1961. Ref.: https://goo.gl/MsPCDg

15. Johnson AR, Milner JJ, Makowski L. The inflammation highway: metabolism accelerates inflammatory traffic in obesity. Immunol Rev. 2012; 249: 218-238. Ref.: https://goo.gl/vPMfUy

16. Young JH. Evolution of blood pressure regulation in humans. Curr Hypertens Rep. 2007; 9: 13-18. Ref.: https://goo.gl/R8g7Db

17. Zhou, MS Aimei Wang, Hong Yu. Link between insulin resistance and hypertension: What is the evidence from evolutionary biology? Diabetol Metab Syndr. 2014; 6: 12. Ref.: https://goo.gl/DJE5Hk

18. Straub RH. Evolutionary medicine and chronic inflammatory state-known and new concepts in pathophysiology. J Mol Med (Berl). 2012; 90: 523-534. Ref.: https://goo.gl/1SzE9M

19. Machnik A, Dahlmann A, Kopp C, Goss J, Wagner H, et al. Mononuclear phagocyte system depletion blocks interstitial tonicity-responsive enhancer binding protein/vascular endothelial growth factor C expression and induces salt-sensitive hypertension in rats. Hypertension. 2010; 55: 755-761. Ref.: https://goo.gl/C8D4xU

20. Machnik A, Neuhofer W, Jantsch J, Dahlmann A, Tammela T, et al. Macrophages regulate saltdependent volume and blood pressure by a vascular endothelial growth factor-C-dependent buffering mechanism. Nat Med. 2009; 15: 545-552. Ref.: https://goo.gl/4B0Nv1

21. Blackburn GL. Pasteur's Quadrant and malnutrition. Nature. 2001; 409: 397-401. Ref.: https://goo.gl/1p9hVl

22. Straub RH. Concepts of evolutionary medicine and energy regulation contribute to the etiology of systemic chronic inflammatory diseases. Brain Behav Immun. 2011; 25: 1-5. Ref.: https://goo.gl/oOORDj

23. Horita S, Seki G, Yamada H, Suzuki M, Koike K, et al. Insulin resistance, obesity, hypertension, and renal sodium transport. Int J Hypertens. 2011; 2011: 391762. Ref.: https://goo.gl/911/gF

24. Soeters MR, Soeters PB. The evolutionary benefit of insulin resistance. Clin Nutr. 2012, 31: 10021007. Ref.: https://goo.gl/cOjYSp

25. Neel JV, Weder AB, Julius S. Type II diabetes, essential hypertension, and obesity as "syndromes of impaired genetic homeostasis": the "thrifty genotype" hypothesis enters the 21 st century. Perspect Biol Med. 1998; 42: 44-74. Ref.: https://goo.gl/PI34Sd

26. Weder AB. Evolution and hypertension. Hypertension. 2007; 49: 260-265. Ref.: https://goo.gl/ooycEF

27. Neel JV. Diabetes mellitus: a "thrifty" genotype rendered detrimental by "progress"? Am J Hum Genet. 1962; 14: 353-362. Ref.: https://goo.gl/26VFzs

28. Hales CN, Barker DJP. The thrifty phenotype hypothesis. Br Med Bull. 2001; 60: 5-20. Ref.: https://goo.gl/aXndOb 
29. Wells JC. The thrifty phenotype: An adaptation in growth or metabolism? Am J Hum Biol. 2011; 23: 65-75. Ref.: https://goo.gl/SaoWdJ

30. Burini RC, de Oliveira EP, Michelin E, McLellan KCP. Epidemic obesity: An Evolutionary Perspective on the Modern Obesity Crisis to a Rationale for a Treatment. In Obesity Epidemic. 2014. Ref.: https://goo.gl/dx86lQ

31. McLellan KCP, Manda RM, Sloan LA, Burini RC. Epigenetics of Glucose Metabolism and the Basis for T2DM Interventions. 2013; 51-70. Ref.: https://goo.gl/sShhhJ

32. Burini RC, Kano HT, Burini FHP, McLellan KCP. Metabolic Syndrome-From the Mismatched Evolutionary Genome with the Current Obesogenic Environment to the Lifestyle Modification as a Primary Care of Free-Living Adults in a Brazilian Community. In: Jody Morton. editor. Metabolic Syndrome: Clinical Aspects, Management Options a53610-723-4nd Health Effects. Nova Science Publ. (NY) ebook. Chap.5, 2017. ISBN:978-1.

33. McDougall I, Brown FH, Fleagle JG. Stratigraphic placement and age of modern humans from Kibish, Ethiopia. Nature. 2005; 433: 733-736. Ref.: https://goo.gl/IImSKu

34. Frassetto LA, Schloetter M, Mietus-Synder M, Morris Jr RC, Sebastian A. Metabolic and physiologic improvements from consuming a paleolithic, hunter-gatherer type diet . Eur J Clin Nutr. 2009; 63: 947-955. Ref.: https://goo.gl/QBvAQq

35. Eaton SB, Konner M. Paleolithic nutrition. A consideration of its nature and current implications. N Engl J Med.1985; 312: 283-289. Ref.: https://goo.gl/W2nFKU

36. Sebastian A, Frassetto LA, Sellmeyer DE, Merriam RL, Morris Jr RC. Estimation of the net acid load of the diet of ancestral preagricultural Homo sapiens and their hominid ancestors. Am J Clin Nutr. 2002; 76: 1308-1316. Ref.: https://goo.gl/qw87WW

37. Di Rienzo A, Hudson RR. An evolutionary framework for common diseases: the ancestralsusceptibility model. Trends Genet. 2005; 21: 596-601. Ref.: https://goo.gl/cfnELI

38. Tsatsoulis A, Mantzaris MD, Bellou S, Andrikoula M. Insulin resistance: an adaptive mechanism becomes maladaptive in the current environment - an evolutionary perspective. Metabolism. 2013; 62: 622-633. Ref.: https://goo.gl/nnhceD

39. Ebbeling CB, Swain JF, Feldman HA, Wong WW, Hachey DL, et al. Effects of dietary composition on energy expenditure during weight-loss maintenance. JAMA. 2012; 307: 2627-2634. Ref.: https://goo.gl/wxACuj

40. Khoshdel AR, Carney SL, Gillies A. Circulatory syndrome: an evolution of the metabolic syndrome concept! Curr Cardiol Rev. 2012; 8: 68-76. Ref.: https://goo.gl/ifomQI

41. Sell $\mathrm{H}$, Habich C, Eckel J. Adaptive immunity in obesity and insulin resistance. Nat Rev Endocrinol. 2012; 8: 709-716. Ref.: https://goo.gl/cTJTGA

42. Murdolo G, Piroddi M, Luchetti F, Tortoioli C, Canonico B, et al. Oxidative stress and lipid peroxidation by-products at the crossroad between adipose organ dysregulation and obesity-linked insulin resistance. Biochimie. 2013; 95: 585-594. Ref.: https://goo.gl/G3xVz3

43. Kahn SE, Hull RL, Utzschneider KM. Mechanisms linking obesity to insulin resistance and type 2 diabetes. Nature. 2006; 444: 840-846. Ref.: https://goo.gl/M6HtkY

44. Lumeng CN, Saltiel AR. Inflammatory links between obesity and metabolic disease. J Clin Invest. 2011; 121: 2111-2117. Ref.: https://goo.gl/FaHmJ9

45. Koppaka S, Kehlenbrink S, Carey M, Li W, Sanchez E, et al. Reduced adipose tissue macrophage content is associated with improved insulin sensitivity in thiazolidinedione-treated diabetic humans. Diabetes. 2013; 62: 1843-1854. Ref.: https://goo.gl/7fcZxD

46. Lumeng $\mathrm{CN}$, Bodzin JL, Saltiel AR. Obesity induces a phenotypic switch in adipose tissue macrophage polarization. J Clin Invest. 2007; 117: 175-184. Ref.: https://goo.gl/0cZInF

47. Shoelson SE, Lee J, Goldfine AB. Inflammation and insulin resistance. J Clin Invest. 2006; 116 1793-1801. Ref.: https://goo.gl/xmRXYi

48. Burini RC, Torezan GA, McLellan KCP. Behavioral risk factors and effects of lifestyle modification on adults with Diabetes: A Brazilian community-based study. Emerging Issues in Medical Diagnosis and Treatment. Concept Press Ltd. 2013; 1.

49. Ruiz-Nunez B, Pruimboom L, Dijck-Brouwer DA, Muskiet FA. Lifestyle and nutritional imbalances associated with Western diseases: causes and consequences of chronic systemic lowgrade inflammation in an evolutionary context. J Nutr Biochem. 2013; 24: 1183-1201. Ref.: https://goo.gl/nTCIWF 
50. Zhou MS, Schulman IH, Zeng Q. Link between the renin-angiotensin system and insulin resistance: implications for cardiovascular disease. Vasc Med. 2012; 17: 330-341. Ref.: https://goo.gl/XaT2EU

51. Muniyappa R, Montagnani M, Koh KK, Quon MJ. Cardiovascular actions of insulin. Endocr Rev. 2007; 28: 463-491. Ref.: https://goo.gl/jyWEhp

52. Schulman IH, Zhou MS. Vascular insulin resistance: a potential link between cardiovascular and metabolic diseases. Curr Hypertens Rep. 2009; 11: 48-55. Ref.: https://goo.gl/2MzOuW

53. Lawrence J, Appel Michael W, Brands Stephen R. Sacks -Dietary Approaches to Prevent and Treat Hypertension: A Scientific Statement From the American Heart Association. Hypertension. 2006; 47: 296-308. Ref.: https://goo.gl/4c9dbx

54. Mancia G, De Backer G, Dominiczak A, Cifkova R, Fagard R, et al. 2007 Guidelines for the Management of Arterial Hypertension: The Task Force for the Management of Arterial Hypertension of the European Society of Hypertension (ESH) and of the European Society of Cardiology (ESC). J Hypertens. 2007; 25: 1105-1187. Ref.: https://goo.gl/KOcH1K

55. Kelley GA, Kelley KS. Progressive resistance exercise and resting blood pressure: a meta- analysis of randomized controlled trials. Hypertension. 2000; 35: 838-843. Ref.: https://goo.gl/aKf1Mt

56. Whelton SP, Chin A, Xin X, He J. Effect of aerobic exercise on blood pressure: a meta-analysis of randomized controlled trials. Ann Intern Med 2002; 136: 493-503. Ref.: https://goo.gl/s86BCw

57. Braith RW, Stewart KJ. Resistance exercise training: its role in the prevention of cardiovascular disease. Circulation. 2006; 113: 2642-2650. Ref.: https://goo.gl/CpdYKC

58. Pescatello LS, Franklin BA, Fagard R, Farquhar WB, Kelley GA, et al. American College of Sports Medicine position stand. Exercise and hypertension. Med Sci Sports Exerc. 2004; 36: 533-553. Ref.: https://goo.gl/2CMOF6

59. Williams MA, Haskell WL, Ades PA, Amsterdam EA, Bittner V, et al. Resistance exercise in individuals with and without cardiovascular disease: 2007 update: a scientific statement from the American Heart Association Council on Clinical Cardiology and Council on Nutrition, Physical Activity, and Metabolism. Circulation. 2007; 116: 572-584. Ref.: https://goo.gl/2ISE1H

60. Cléroux J, Feldman RD, Petrella RJ. Lifestyle modifications to prevent and control hypertension. 4. Recommendations on physical exercise training. Canadian Hypertension Society, Canadian Coalition for High Blood Pressure Prevention and Control, Laboratory Centre for Disease Control at Health Canada, Heart and Stroke Foundation of Canada. Cmaj. 1999; 160: 21-28. Ref.: https://goo.gl/WJNAqW

61. Posch K, Schmidt K, Graier WF. Selective stimulation of L-arginine uptake contributes to shear stress-induced formation of nitric oxide. Life Sci. 1999; 64: 663-670. Ref.: https://goo.gl/0ZWmL

62. Gielen S, Schuler G, Hambrecht R. Exercise training in coronary artery disease and coronary vasomotion. Circulation. 2001; 103: 1-6. Ref.: https://goo.gl/wc0ajv

63. Corson MA, James NL, Latta SE, Nerem RM, Berk BC, et al. Phosphorylation of endothelial nitric oxide synthase in response to fluid shear stress. Circ Res. 1996; 79: 984-991. Ref.: https://goo.gl/HCfkMe

64. Fukai T, Siegfried MR, Ushio-Fukai M, Cheng Y, Kojda G, et al. Regulation of the vascular extracellular superoxide dismutase by nitric oxide and exercise training. J Clin Invest. 2000; 105: 1631-1639. Ref.: https://goo.gl/058dBj

65. Ji LL. Antioxidants and oxidative stress in exercise. Proc Soc Exp Biol Med. 1999; 222: 283-292. Ref.: https://goo.gl/W2rM60

66. Hambrecht R, Wolf A, Gielen S, Linke A, Hofer J, et al. Effect of exercise on coronary endothelial function in patients with coronary artery disease. N Engl J Med. 2000; 342: 454-460. Ref.: https://goo.gl/Wntwn1

67. Appel LJ, Brands MW, Daniels SR, Karanja N, Elmer PJ, et al. American Heart Association. Dietary approaches to prevent and treat hypertension: a scientific statement from the American Heart Association. Hypertension. 2006; 47: 296-308. Ref.: https://goo.gl/60lBlx

68. Sacks FM, Campos H. Dietary therapy in hypertension. N Engl J Med. 2010; 362: 2102-2112. Ref.: https://goo.gl/4w4x1R

69. Appel LJ, Moore TJ, Obarzanek E, Vollmer WM, Svetkey LP, et al. A clinical trial of the effects of dietary patterns on blood pressure. DASH Collaborative Research Group. N Engl J Med. 1997; 336: 1117-1124. Ref.: https://goo.gl/fplxqn 
70. Sacks FM, Svetkey LP, Vollmer WM, Appel LJ, Bray GA, et al. Effects on blood pressure of reduced dietary sodium and the Dietary Approaches to Stop Hypertension (DASH) diet. DASH- Sodium Collaborative Research Group. N Engl J Med. 2001; 344: 3-10. Ref.: https://goo.gl/Ua94vR

71. Appel LJ, Sacks FM, Carey VJ, Obarzanek E, Swain JF, et al. Effects of protein, monounsaturated fat, and carbohydrate intake on blood pressure and serum lipids: results of the OmniHeart randomized trial. JAMA. 2005; 294: 2455-2464. Ref.: https://goo.gl/GQE7SY

72. Psaltopoulou T, Naska A, Orfanos P, Trichopoulos D, Mountokalakis T, et al. Olive oil, the Mediterranean diet, and arterial blood pressure: the Greek European Prospective Investigation into Cancer and Nutrition (EPIC) study [published correction appears in Am J Clin Nutr. 2005; 81: 1181]. Am J Clin Nutr. 2004; 80: 1012-1018. Ref.: https://goo.gl/F8m1Fn

73. Núñez-Córdoba JM, Valencia-Serrano F, Toledo E, Alonso A, Martínez- González MA. The Mediterranean diet and incidence of hypertension: the Seguimiento Universidad de Navarra (SUN) Study. Am J Epidemiol. 2009; 169: 339-346. Ref.: https://goo.gl/BuCbn3

74. Lifton RP, Wilson FH, Choate KA, Geller DS. Salt and blood pressure: new insight from human genetic studies. Cold Spring Harb Symp Quant Biol. 2002; 67: 445-450. Ref.: https://goo.gl/zWKyzf

75. Whelton PK, Appel LJ, Espeland MA, Applegate WB, Ettinger WH Jr, et al. Sodium reduction and weight loss in the treatment of hypertension in older persons: a randomized controlled Trial of Nonpharmacologic Interventions in the Elderly (TONE): TONE Collaborative Research Group. JAMA. 1998; 279: 839-846. Ref.: https://goo.gl/QmzO06

76. Knowler WC, Barrett-Connor E, Fowler SE, Hamman RF, Lachin JM, et al. Reduction in the incidence of type 2 diabetes with lifestyle intervention or metformin. N Engl J Med. 2002; 346: 393-403. Ref.: https://goo.gl/0tMAZS

77. Vollmer WM, Sacks FM, Ard J, Appel LJ, Bray GA, et al. Effects of diet and sodium intake on blood pressure: subgroup analysis of the DASH-sodium trial. Ann Intern Med. 2001; 135: 1019 -1028. Ref.: https://goo.gl/x1EEi4

78. Bray GA, Vollmer WM, Sacks FM, Obarzanek E, Svetkey LP, et al. A further subgroup analysis of the effects of the DASH diet and three dietary sodium levels on blood pressure: results of the DASHSodium Trial. Am J Cardiol. 2004; 94: 222-227. Ref.: https://goo.gl/g0dKe6

79. Klag MJ, Whelton PK, Appel LJ. Effect of age on the efficacy of blood pressure treatment strategies. Hypertension. 1990; 16: 700-705. Ref.: https://goo.gl/fmrdpf

80. Giles WH, Kittner SJ, Hebel JR, Losonczy KG, Sherwin RW. Determinants of black-white differences in the risk of cerebral infarction: the National Health and Nutrition Examination Survey Epidemiologic Follow-up Study. Arch Intern Med. 1995; 155: 1319-1324. Ref.: https://goo.gl/Ta5DAQ

81. Ayala C, Greenlund KJ, Croft JB, Keenan NL, Donehoo RS. Racial/ethnic disparities in mortality by stroke subtype in the United States, 1995-1998. Am J Epidemiol. 2001; 154: 1057-1063. Ref.: https://goo.gl/tlytjU

82. Klag MJ, Whelton PK, Randall BL, Neaton JD, Brancati FL. Blood pressure and end-stage renal disease in men. $\mathrm{N}$ Engl J Med. 1996; 334: 13-18. Ref.: https://goo.gl/AZrgZg

83. Institute of Medicine. Dietary Reference Intakes: Water, Potassium, Sodium Chloride, and Sulfate. 1st ed. Washington, DC: National Academy Press; 2004.

84. Marion J. Franz-Medical Nutrition Therapy for Hypertension and Albuminuria. Diabetes Spectrum 2006; 19: 32-38

85. Miller ER 3rd, Erlinger TP, Young DR, Jehn M, Charleston J, et al. Results of the Diet, Exercise, and Weight Loss Intervention Trial (DEW-IT). Hypertension. 2002; 40: 612-618. Ref.: https://goo.gl/y6UT40

86. Appel LJ, Champagne CM, Harsha DW, Cooper LS, Obarzanek E, et al. Effects of comprehensive lifestyle modification on blood pres-sure control: main results of the PREMIER clinical trial. JAMA. 2003; 289: 2083-2093. Ref.: https://goo.gl/Sspx25

87. Greenland P. Beating high blood pressure with low-sodium DASH. N Engl J Med. 2001; 344: 53-55. Ref.: https://goo.gl/Bp5FMp

88. Joffres MR, Campbell NR, Manns B, Tu K. Estimate of the benefits of a population-based reduction in dietary sodium additives on hypertension and its related health care costs in Canada. Can $J$ Cardiol. 2007; 23: 437-443. Ref.: https://goo.gl/oYHIn4

89. Waib $\mathrm{PH}$, Papini-Berto SJ, Habermann F, Burini RC-Calcium-intake assessment in essential-arterial hypertensive patients. Rev. Saúde públ. S. Paulo. 26: 27 - 33, 1992. 
90. IBGE.gov.br, [Internet]. Brasilia: Instituto Brasileiro de Geografia e Estatística; c2009. Available from: https://goo.gl/ZH6zaH

91. Takahashi MM, de Oliveira EP, de Carvalho AL, de Souza Dantas LA, Burini FH. Metabolic syndrome and dietary components are associated with coronary artery disease risk score in free-living adults: a cross-sectional study. Diabetology \& Metabolic Syndrome. 2011; 3: 7. Ref.: https://goo.gl/QIOrul

92. Bach-Faig A, Berry EM, Lairon D, Reguant J, Trichopoulou A, et al. Mediterranean Diet Foundation Expert Group. Mediterranean diet pyramid today. Science and cultural updates. Public Health Nutr. 2011; 14: 2274-2284. Ref.: https://goo.gl/j5tYYO

93. Brandt N. Evolutionary and Geological Timelines. 2007.

94. Oliveira EP, Camargo KF, Castanho GKF, Nicola M, Portero-McLellan KC, et al. Dietary Variety is a Protective Factor for Elevated Systolic Blood Pressure.Arq Bras Cardiol. 2012; 98: 338-343. Ref.: https://goo.gl/OFLxgE

95. Lastra G, Dhuper S, Johnson MS, Sowers JR. Salt, aldosterone, and insulin resistance: impact on the cardiovascular system. Nat Rev Cardiol. 2010; 7: 577-584. Ref.: https://goo.gl/uMtDiQ

96. Oliveira RZ, Nogueira JL. Hipertensão arterial no município de Cianorte, estado do Paraná, Brasil. Acta Sci Health Sci. 2003; 25: 75-79. Ref.: https://goo.gl//40tuo

97. Taylor RS, Ashton KE, Moxham T, Hooper L, Ebrahim S. Reduced dietary salt for the prevention of cardiovascular disease: a meta-analysis of randomized controlled trials (Cochrane review). Am J Hypertens. 2011; 24: 843-853. Ref.: https://goo.gl/yWIEcL

98. Whelton PK, He J, Muntner P. Prevalence, awareness, treatment and control of hypertension in North America, North Africa and Asia. J Hum Hypertens. 2004; 18: 545-51. Ref.: https://goo.gl/TzdfmM

99. Xu H, Barnes GT, Yang Q, Tan G, Yang D, et al. Chronic inflammation in fat plays a crucial role in the development of obesity-related insulin resistance. J Clin Invest. 2003; 112: 1821-1830. Ref.: https://goo.gl/gwj077

100. Zhou MS, Schulman IH, Raij L. Vascular inflammation, insulin resistance, and endothelial dysfunction in salt-sensitive hypertension: role of nuclear factor kappa B activation. J Hypertens. 2010; 28: 527535. Ref.: https://goo.gl//dCQHr 